ENTREPRENEURSHIP AND SUSTAINABILITY ISSUES

ISSN 2345-0282 (online) http://jssidoi.org/jesi/

2020 Volume 7 Number 3 (March)

http://doi.org/10.9770/jesi.2020.7.3(2)

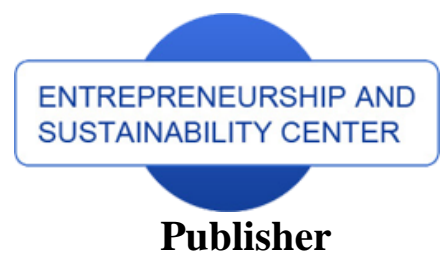

http://jssidoi.org/esc/home

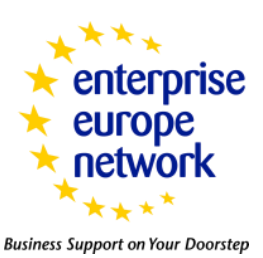

CASPA

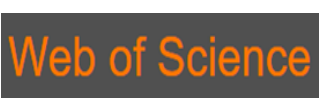

Clarivate
Analytics

\title{
THE CAUSAL FACTORS INFLUENCING CORPORATE SUSTAINABILITY PERFORMANCE: CASE OF COMMUNITY SMES IN THREE SOUTHERN BORDER PROVINCES, THAILAND*
}

\author{
Dussadee Nakruang ${ }^{1}$, Kwunkamol Donkwa ${ }^{2}$, Adisak Suvittawat ${ }^{3}$ \\ ${ }^{1,2,3}$ Institute of Social Technology, Suranaree University of Technology, Nakhon Ratchasima 30000, Thailand \\ E-mails: ${ }^{1}$ dussadee.n@yru.ac.th, ${ }^{2}$ kwnkamol@sut.ac.th,${ }^{3}$ adisak@sut.ac.th
}

Received 17 July 2019; accepted 10 January 2020; published 30 March 2020

\begin{abstract}
The business sector has started to understand and follow business management that creates a balance between economy, society, and environment for the strength, stability, and sustainability of the business and society as a whole. However, the matter remains a challenge for many organizations, especially for Small and Medium Enterprises (SMEs) businesses. This research aims 1) to analyze the direct influence of entrepreneurial orientation on the corporate sustainability performance of community enterprises in the three southern border provinces and 2) to analyze the indirect influence of entrepreneurial orientation on corporate sustainability performance through the mediator variable which is knowledge integration capability of community enterprises in the three southern border provinces. This research uses an organizational level analysis unit and uses Structural Equation Modeling (SEM) on data collection via questionnaires of 384 community enterprises in three southern border provinces. The sampling was done by multi-stages level and stratified sampling using proportions and specific selection. The results of the research showed that the results of the consistency of the structural equation modeling of the cause and effect factors affecting the corporate sustainability performance of community enterprises of three southern border provinces, consistent with the empirical data at a good level. The entrepreneurial orientation had a direct effect on knowledge integration capability with the highest influence coefficient. In addition, the entrepreneurial orientation had an indirect influence on corporate sustainability performance through knowledge integration capability.
\end{abstract}

Keywords: corporate sustainability performance; entrepreneurial orientation; knowledge integration capability; small and medium enterprises

Reference to this article should be made as follows: Nakruang, D., Donkwa, K., Suvittawat, A. 2020. The causal factors influencing corporate sustainability performance: case of community smes in three southern border provinces, Thailand. Entrepreneurship and Sustainability Issues, 7(3), 1459-1471. https://doi.org/10.9770/jesi.2020.7.3(2)

JEL Classifications: D83, L25, L26, M12

\footnotetext{
* The research was supported by Office of the Higher Education Commission for allocating a national PhD scholarship in the project to develop teachers and personnel for higher education institutions in the development zone of the southern border provinces for the year 2018. Data was collected from the research samples that have passed the approval of the Human Research Program in Humanities and Social Sciences, Suranaree University of Technology, Thailand. Project Code EC-62-003.
} 


\section{ENTREPRENEURSHIP AND SUSTAINABILITY ISSUES}

ISSN 2345-0282 (online) http://jssidoi.org/jesi/

2020 Volume 7 Number 3 (March)

http://doi.org/10.9770/jesi.2020.7.3(2)

\section{Introduction}

The implementation results of the sustainability performance are the basis for the success of businesses in the $21^{\text {st }}$ century. If SMEs are striving to solve social and environmental problems by enable businesses to innovate and compete amid rapid changes in the global economy. Thai economy with limited resources, SMEs should have a sustainability perspective as a competitive path. The concept of sustainability performance is the responsibility of the organization that gives importance to the economy, society and environment that deliver the profits of the business and create sustainability for the business (Fred, Forest 2015) by the sustainable development of the organization from 3 Ps: People, Planet and Profit. Businesses are sustainable that will be responsible for the relationship of the Triple Bottom Line (TBL) concept which is consisted of the economic, environmental and social dimensions (Elkington 1997).

Many literature reviews and related research studies support the view that entrepreneurial orientation affects the organization's performance. The concept of entrepreneurship is a measure of the nature of entrepreneurs who have the desire to initiate products, a new brand or a new process for creating competitive opportunities (Covin, Green, Slevein 2006). However, there is a small amount of research that studied the mediator variables of entrepreneurial orientation (EO) and corporate sustainability performance (CSP). From the literature review, there are important variables that affect CSP, namely the concept of knowledge integration capability (KIC). The sustainable advantages related to the ability and resources of each organization to create a competitive advantage by utilizing existing ability and internal and external performance to manage internal and external environment changes. In accordance, the concept of KIC is creating and applying knowledge both inside and outside the organization to produce products and services, an effective ability is important to business organizations. However, innovation involves KIC that leads to a sustainable competitive advantage (Grant 1996). Moreover, it was found that EO had a clear relationship with the EO and activities of EO affecting the organization performance (Kim et al. 2012).

To create competitive advantages, we should strengthen the foundation economy, such as community enterprises which are formed by people in the community, who have gathered people to conduct business with many grassroots levels. This local business is not yet the level of Small and Medium Enterprises (SMEs) or cooperatives. However, community business can help the economy of a certain level to create a welfare system for itself and create immunity for groups or communities. Moreover, it was found that community entrepreneurs still face problems in the strength of businesses, especially marketing, financial, information technology problems, and production cost (Na Sakon Nakhon, Sangkharat 2012). For the review of literature related to the CSP of community enterprises in the three southern border provinces mentioned above. Therefore, we need to study the empirical data to test the influence of factors of EO on indirect effects on CSP of community enterprises through the KIC in the context of the three southern border provinces to create new knowledge on such issues. The three southern border provinces have lowest Gross Provincial Product (GPP) in Thailand such as Narathiwat, Yala and Pattani GPP are 42,737 43,369 and 55,738 million baht respectively (National Statistical Office 2560). Most people did rubber plantation and fishery that caused the creation of Productivity per person of the population and the economic growth is lower than other regions. These areas still need to solve economic problems with continuous support from the government in order to improved economy. This research aims to analyze the direct influence of EO on sustainable results, and to analyze the indirect influence of EO on CSP through the mediator variable which is the KIC of community enterprises in the three southern border provinces. 


\section{ENTREPRENEURSHIP AND SUSTAINABILITY ISSUES}

ISSN 2345-0282 (online) http://jssidoi.org/jesi/

2020 Volume 7 Number 3 (March)

http://doi.org/10.9770/jesi.2020.7.3(2)

\section{Literature Review}

\subsection{Corporate Sustainability Performance (CSP)}

Based on the study of relevant research, it was found that the principle of CSP is more important today, for both organizational theory and implementation. However, it still lacking clarity of the sustainability of the organization, as how to achieve success. The organizational performance measures are two types such as financial performance measured by economic factors and non-financial performance results (Zehir, Can, Karaboga 2015). The CSP is a two-dimensional combination of environmental performance and social performance indicators (Awan et al. 2017). The responsibilities of social, environmental and economic are major goals of the organization. Especially, environmental-oriented entrepreneurs will have a positive influence on environmental performance and financial performance (Tuğçe, Vayvaya 2016; Jiang et al. 2018; El Idrissi et al. 2020). Companies are interested in domestic trade that they will deal with the production without pollution, and environmental friendliness to the host country. As the increase in organizations in developed countries use TBL in the organization's performance, measured by people, profits and our world. This measure does not focus on profits to measure growing performance (Zhang et al. 2018). As for the green technology dynamics, there is a negative correlation between environmental-oriented entrepreneurs and environmental performance. In addition, the Balanced Scorecard (BSC) is directly related to the management and long-term strategies change to manage the organization's performance. Therefore, the BSC framework balances between financial and non-financial indicators and BSC is a good tool to measure the results of sustainability performance results. Moreover, the concept of Sustainable Balanced Scorecard (SBSC) demonstrates what to measure and what should do to enable the organization to improve sustainability performance (Lesáková, Dubcováb 2016; Nikolaou, Tsalis 2013). The sustainability-focused entrepreneurs are opposed to the economic aspect in that they share a place taking into account social benefits and self-interest. In addition, it was found that the founders of a sustainable business organization will have a decision-making process or an organization's policy that combines the value of sustainability in a formal and informal form. In the first competition, environmental-oriented entrepreneurs will have a positive influence on the results of environmental operations and financial performance. As for the green technology dynamics, there is a negative relationship with entrepreneurs who focus on the environment and environmental performance (Salzmann et al. 2005; DiVito, Bohnsack 2017).

\subsection{Knowledge Integration Capability (KIC)}

The important knowledge of the organization and information technology can adjust the knowledge model to implement employees that help to share and integrate their knowledge effectiveness (Basagliaa, Caporarello, Magni, Pennarolab 2010). All knowledge management process is very important to organizational performance (Shiaw-Tong et al. 2016). Knowledge can be completed with the KIC that the service business focuses on projects in its operation not only simplifies knowledge management process in services innovation process, but there is also evidence to support the competitive advantage of service innovation that can be sustainable. In addition, new knowledge acquired from inside and outside the organization that may not be enough effectiveness, therefore we should integrate existing knowledge in order to create a solution for innovative services that meet the customers' need (Salunke et al. 2018).

The organization climate is important to the ability to integrate information technology, and it affects team work as well. The process that results in successful performance is due to creation, conversion and exchanging of knowledge, which have a positive influence on organization performance (Tanriverdi 2005). Therefore, the knowledge needs, skills, and abilities of employees are essential, especially technology and new processes that will be apply in the market (Ivanov, Avasilcăi 2014). Moreover, EO can drive the maximum entrepreneur's efficiency performance. As for the transfer of knowledge and integration of various types of knowledge, there is a 


\section{ENTREPRENEURSHIP AND SUSTAINABILITY ISSUES}

ISSN 2345-0282 (online) http://jssidoi.org/jesi/

2020 Volume 7 Number 3 (March)

http://doi.org/10.9770/jesi.2020.7.3(2)

positive correlation between environmental performance and financial performance (Montoya et al. 2017; Jiang et al. 2018).

\subsection{Entrepreneurial Orientation (EO)}

All autonomy, risk taking, proactiveness and competitive aggressiveness variables have statistical significance (Zehir et al. 2015). Risk taking has a positive influence on entrepreneurial orientation but risk taking is not related to EO of small entrepreneurs (Josien 2012). Proactive actions will affect the rapid development of innovation (Shan et al.2016). EO and firm performance in country have significant statistical variance (Semrau et al. 2016). Additional, new entrepreneurs have characteristics of EO that can manage business better than another (Shan et al. 2016; Hult et al. 2003). The fluctuating environment may have positive and negative effects on organization performance encouraging the organization to have better performance (Pratono, Mahmood 2015). The organizational or corporate innovative capabilities have a positive relationship with the performance results of the organization (Atalaya et al. 2013).

The EO, as an indication of the firm's processes, structures and behavior to take opportunities, can help us greater depth understanding how sustainable entrepreneurs manage this paradox of entrepreneurial enterprising within limits of economic, ecological and social responsibility. So, the different configurations of EO in accordance with the sustainability decision profiles and we extend the literature by showing how the reflexivity of EO interacts with sustainability orientation (DiVito, Bohnsack 2017). In addition, EO activated by grassroots innovation significantly influence entrepreneurial success in the Indian context (Singh et al. 2019). Moreover, when we use separate or combine the influence of strategic drivers (entrepreneurial orientation, market orientation and knowledge management orientation) over cleaner production, there is a higher chance of cleaner production success, with a significant increase in sustainable competitive advantage for the small and medium enterprises (Guimarães et al. 2018).

Therefore, to make the research results consistent with the objectives set, the following important research hypotheses have been formulated.

$\mathrm{H}_{1}$ : Entrepreneurial orientation has a positive direct influence on the corporate sustainability performance of community enterprises.

$\mathrm{H}_{2}$ : Entrepreneurial orientation has a positive direct influence on the knowledge integration capability.

$\mathrm{H}_{3}$ : Entrepreneurial orientation has indirect influence on the corporate sustainability performance of community enterprises through the knowledge integration capability.

\section{Conceptual Framework}

This research based on the concept of CSP, EO and KIC. EO is potentially important to entrepreneurship consists of innovativeness, risk taking, competitive aggressive, proactive and autonomy (Li et al. 2009; Muchiri 2013) that describes a fairly consistent set of related activities and process. KIC is a concept based on learning culture, knowledge management process capability and information technology capability which enable the organization generate knowledge regarding its competition and economic environment changes (Garvin 1993; Grant 1996; Kim, Sanders 2002; Ryu et al. 2005; Kim et al. 2012). CSP can identify manage and measure the drivers of improve sustainability in systems and structure that consists of social performance, environmental performance and economic performance such as financial, learning and growth, internal and customer perspectives (Prajogo 2007; Josien 2012; Kaplan, Norton, 1996, 1997, Sebhatu 2008; Cantele, Zardini 2018). From the relevant 


\section{ENTREPRENEURSHIP AND SUSTAINABILITY ISSUES}

ISSN 2345-0282 (online) http://jssidoi.org/jesi/

2020 Volume 7 Number 3 (March)

http://doi.org/10.9770/jesi.2020.7.3(2)

literature, explained that EO and KIC effect to competitive advantage in the long run (Gold et al. 2001, Kim et al. 2012; Jiang et al. 2018). Therefore, the conceptual framework of this research as figure 1:

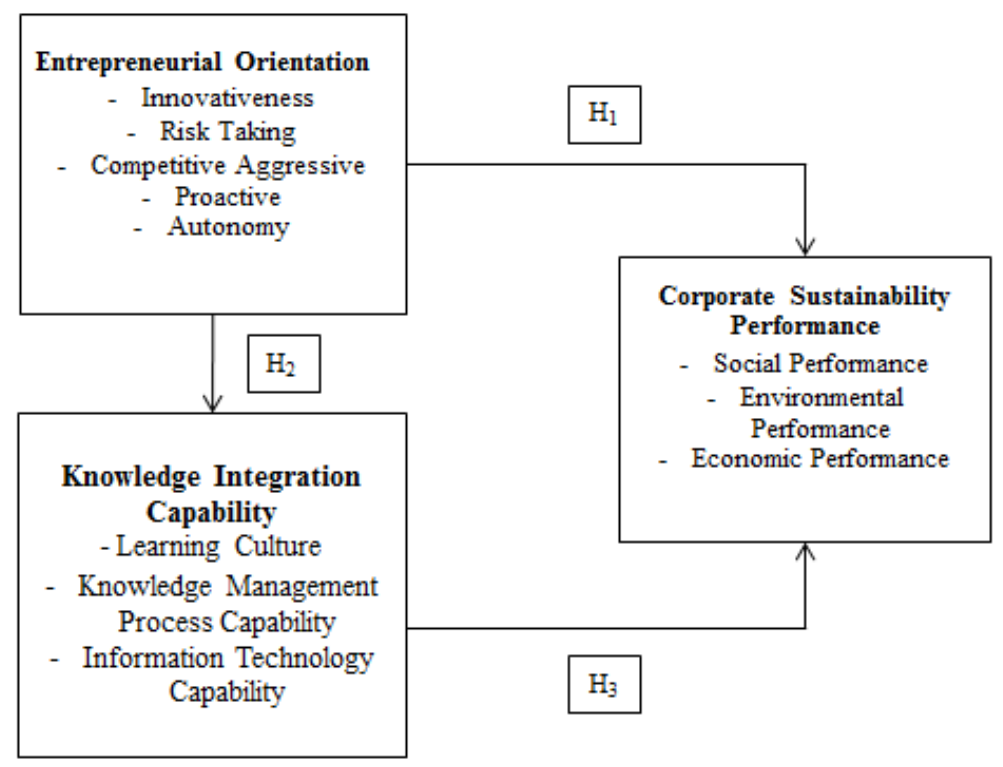

Figure 1. Conceptual framework

\section{Research Methods}

This research is a quantitative analysis of a survey research which has a method to collect data using questionnaires as a tool.

The population are 1,036 groups of community enterprises in the three southern border provinces, namely, Yala, Pattani and Narathiwat, (Agricultural Offices in Yala, Pattani and Narathiwat 2016) with particular emphasis on group leaders / group committees or those involved in the management of community enterprises in the three southern border provinces that have a good level of strength with a minimum of 3 years of continuous operations. The large sample group will give more accurate statistical calculations than small samples (Wiersma, Jurs 2009). The sample size should be at least 300 samples (Norusis 2010). Therefore, this study has determined the size of the sample group used in the study of at least 384 community enterprises by collecting 1 sample questionnaire per 1 community enterprise group by which 2-3 committee members or members of the community enterprise group responded using a multi-stage sampling method, i.e. non-probability sampling by using purposive sampling, probability sampling by using stratified random sampling and quota sampling, based on the population that is proportional to the number of community enterprise groups in the three southern border provinces.

The questionnaire included three constructs dedicated to CSP, five constructs dedicated to EO and three constructs dedicated to KIC measuring the possible mediator in CSP and EO relationship. The questionnaire provides the target sample group is self-report. The whole set of questionnaires has $\alpha$ Coefficient of 0.983 . Compared to the criteria (Kline 2011), it is considered "Very good" and the Index of Item Objective Congruence: IOC is in the range of 0.67 to 1.00 higher than 0.50 (Rovinelli \& Hambleton 1977).

We used Confirmatory Factor Analysis (CFA) and analyzed to test hypotheses. The SEM analysis for structural relationship analysis of causal factors affecting the CSP of community enterprises in three southern border 


\section{ENTREPRENEURSHIP AND SUSTAINABILITY ISSUES}

ISSN 2345-0282 (online) http://jssidoi.org/jesi/

2020 Volume 7 Number 3 (March)

http://doi.org/10.9770/jesi.2020.7.3(2)

provinces was conducted by examining the consistency of the structured model defined with empirical data, and by studying the direct/indirect influence and the total influence of EO on the CSP of community enterprises in the three southern border provinces. The analysis was done using computer software.

\section{Results}

Before analyzing SEM, we have checked the completed questionnaires that received from the respondents. The results of skewness is between -0.326 and -0.054 and kurtosis is between -0.082 and 0.104 that the criteria of skewness is not more than 3 and kurtosis is not more than 10 (Kline 2011). The results show that data has a normal distribution. Therefore, it is appropriate to analyses SEM. The overall results of the measurement model, factor loading (raw score) show that all observed variables relate with latent variables for a significance level of .01 (Hair et al. 2010). Standardized factor loading in all variables are between 0.73 and 0.89 . From the criteria of Hair et al. (2010) explained that factor loadings should equal or more than 0.5 that mean all observed variables of each latent variables have high covariance.

The accuracy of latent variable is good level that Construct Reliability (CR) should equal or more than 0.7 (Hair et al., 2010). This measurement model showed that latent variable is between 0.82 and 0.91 . This result explains that all latent variables in this measurement model have high reliability. Average Variance Extracted (AVE) of latent variables is between 0.60 and 0.79 that are more than 0.5 as acceptance criteria (Hair et al. 2010). The results are no error in the measurement that causes variations in the observed variable more than the directed latent variable. Regression coefficients $\left(\mathrm{R}^{2}\right)$ explain about the validity of each observed variables. High Regression coefficients mean high validity. This results show that $\mathrm{R}^{2}$ is between 0.50 and 0.80 that almost observed variables are high stability to explain covariance of each latent variable.

The finding revealed that the majority of respondents are Pattani community enterprises (63.3\%) follow by Narathiwat community enterprises (19.3\%) and Yala community enterprises (17.4\%). The majority of them managed processed and produced food $(53.1 \%)$ follow by agricultural products $(15.1 \%)$. They almost used resource inside and outside their local area $(56.0 \%)$. The levels of performance or opinions are following as table 1.

Table 1 Arithmetic mean and standard deviation of level of variables

\begin{tabular}{lcc}
\hline Variables & Mean $(\bar{X})$ & Standard Deviation (S.D.) \\
\hline Entrepreneurial Orientation & $\mathbf{3 . 8 1}$ & $\mathbf{0 . 5 2}$ \\
Innovativeness & 3.81 & 0.55 \\
Risk Taking & 3.82 & 0.60 \\
Competitive Aggressiveness & 3.77 & 0.62 \\
Proactiveness & 3.74 & 0.65 \\
Autonomy & 3.91 & 0.59 \\
Knowledge Integration Capability & $\mathbf{3 . 7 4}$ & $\mathbf{0 . 5 9}$ \\
Learning Culture & 3.92 & 0.61 \\
Knowledge Management Process Capability & 3.79 & 0.63 \\
Information Technology Capability & 3.52 & 0.73 \\
Corporate Sustainability Performance & $\mathbf{3 . 8 2}$ & $\mathbf{0 . 5 6}$ \\
Social Performance & 3.93 & 0.64 \\
Environmental Performance & 3.73 & 0.65 \\
Economic Performance & 3.79 & 0.65 \\
\hline
\end{tabular}

The highest of performance or opinions are CSP $(\bar{X}=3.82)$, EO ( $\bar{X}=3.81)$ and KIC $(\bar{X}=3.74)$ respectively. The result of observed variable of CSP found that social performance has highest opinion $(\bar{X}=3.93)$. The highest performance of observed variable of EO is risk taking $(\bar{X}=3.82)$ and learning culture as observed variable of KIC has the highest opinion $(\bar{X}=3.92)$. 
The results are mentioned by objectives as follows:

1. It was found that Chi-square Statistic: $\chi^{2}$ is equal to 111.655 , df to $41, \mathrm{p}$-value to .000 . That means the statistic of the Chi-square is statistically significant, which is usually considered not to meet the specified criteria. But from the feedback given by Hair et al. (2010), in the case of more than 250 samples and 1329 observed variables, the chi-square statistic is expected to be insignificant. For this study, data was collected from 384 community enterprises in the three southern border provinces and 14 observed variables. Therefore, when comparing those suggestions, it was considered that Chi-square statistic has passed the criteria. However, the Chi-Square statistic has limitations in that it depends on the sample size. Therefore, other statistical values should be considered, such as the normed chi-square ( $\left.\chi^{2} / \mathrm{df}\right)$, which is the ratio between the chi-square $\left(\chi^{2}\right)$ and the degree of freedom (df) of less than 3.00 (Hair et al. 2010). The results showed that there was a normed chi-square ( $\left.\chi^{2} / \mathrm{df}\right)$ equal to 2.723 indicating that it met the criteria. For the root mean square error of approximation (RMSEA), it is found that the value is 0.067 which is less than the specified criteria. The results of the examination, therefore, indicate that the criteria are consistent with the evaluation by the standardized root mean residual (SRMR). It is also found that the value is 0.01 . The results further indicate that the criteria as well as the comparative fit index (CFI) have a value of 0.978 . The results indicate that it also met the criteria. Therefore, it could be concluded that the model for measuring the results of the established sustainability performance variables is consistent with empirical data as figure 1 and table 2 .

2. From figure 2 and table 3 showed the coefficient of direct effect, indirect effect and the total effect of the structural equation model (Standard Score). It was found that the variables influence on CSP is KIC. EO had not direct effect on CSP at statistical significance with a coefficient of influence equal to 0.20 which is a denial of Hypothesis 1. However, it was found that EO variables had a direct effect on KIC with statistical significance at the level of .01. The highest influence coefficient was 0.91 , which followed Hypothesis 2 . When considering indirect influential of EO variable towards CSP through KIC with statistical significance at the level of .01, the influence coefficient is equal to 0.72 , which followed Hypothesis 3.

3. The results showed that EO and KIC could explain the variance of CSP (94.0\%) and EO had indirect effect on CSP through KIC. Community enterprises will do their business to have sustainable performance that should raise the process of KIC such as knowledge creating, sharing, transferring and application for members in order to improve sustainable performance. SEM is presented in Figure 2 below. 


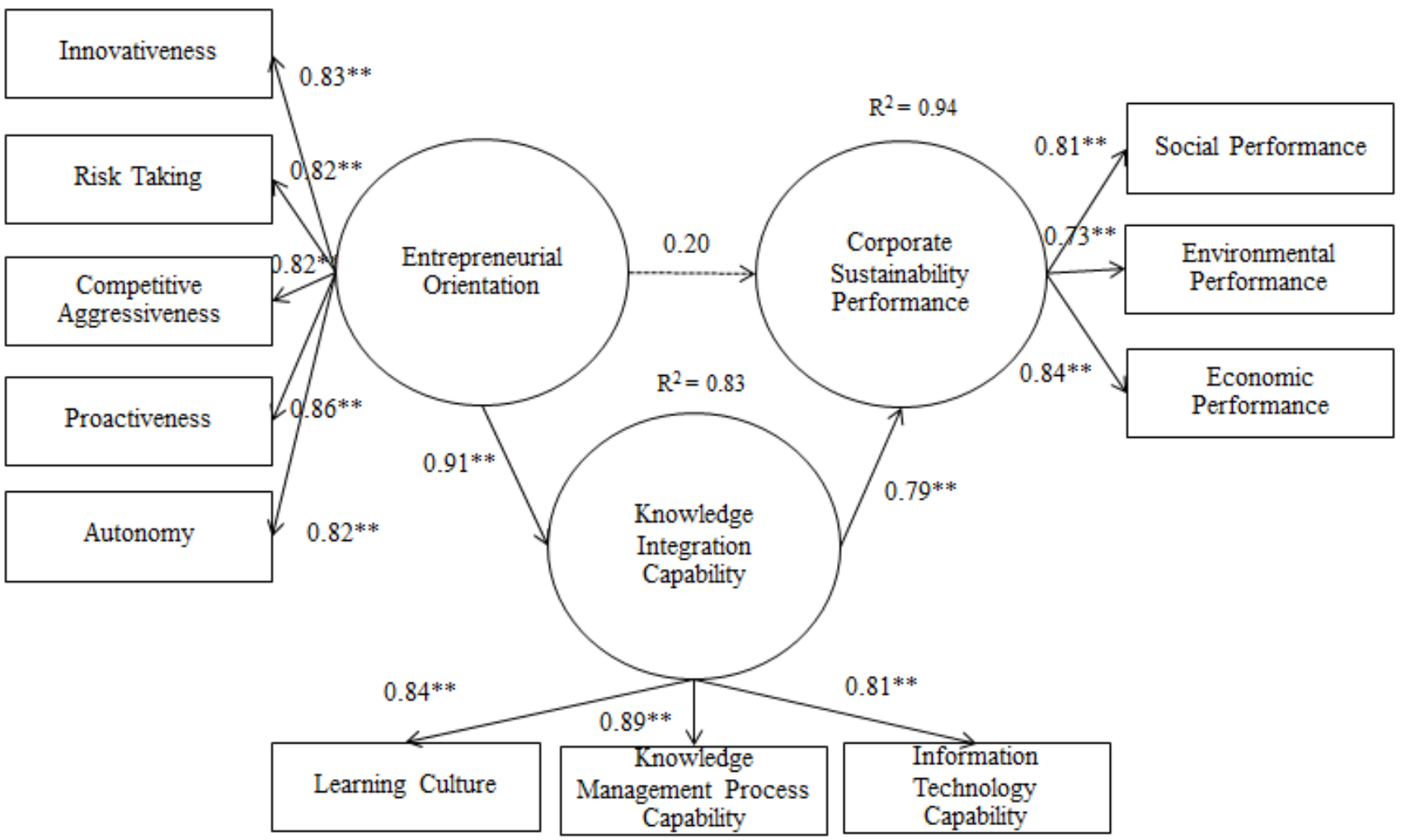

Chi-square $=111.655, \mathrm{df}=41, \mathrm{p}=0.00, \mathrm{RMSEA}=0.067, \mathrm{SRMR}=0.01, \mathrm{CFI}=0.978$

$* * \mathrm{p}<.01$

Figure 2. Structural Equation Modeling (Standardized Estimates)

Table 2. Assessment of the consistency of structural equation modeling with empirical data

\begin{tabular}{|c|l|l|l|}
\hline Consistency Index & Criteria & P-Values & Analysis \\
\hline $\begin{array}{c}1 . \quad X^{2} \\
\text { or } X^{2} / \mathrm{df}\end{array}$ & $\mathrm{p}<.05$ (Significant) & 0.00 & No-Passed \\
\hline $2 . \quad$ RMSEA & Less than 5.00 & Less than $0.05-0.08$ & Passed \\
\hline 3. SRMR & $\begin{array}{l}\text { Less than or Equal to } 0.80) \text { together with } \\
\text { CFI more than } 0.92(\end{array}$ & 0.01 & Passed \\
\hline 4. $\quad$ CFI & More than 0.92 & 0.978 & Passed \\
\hline
\end{tabular}

Table 3 Coefficient of direct effect (DE) and indirect effect (IE) and total effect (TE) of the structural equation model (Standard Score)

\begin{tabular}{|l|l|l|l|}
\hline Variables & DE & IE & TE \\
\hline EO $\rightarrow$ CSP & $0.20^{\mathrm{ns}}$ & - & $0.20^{\mathrm{ns}}$ \\
\hline $\mathrm{EO} \rightarrow$ KIC & $0.91^{* *}$ & - & $0.91^{* *}$ \\
\hline $\mathrm{EO} \rightarrow$ KIC $\rightarrow$ CSP & - & $0.72^{* *}$ & $0.72^{* *}$ \\
\hline
\end{tabular}

$* * \mathrm{p}<.01, \mathrm{~ns}=$ not significant 


\section{ENTREPRENEURSHIP AND SUSTAINABILITY ISSUES}

ISSN 2345-0282 (online) http://jssidoi.org/jesi/

2020 Volume 7 Number 3 (March)

http://doi.org/10.9770/jesi.2020.7.3(2)

\section{Discussion}

From the results, EO had not direct effect on CSP with statistical significance. Community enterprises were driven by key person only group leader is not enough to reach their goal because this business relies on the cooperation between the leaders and group members. The group leader has knowledge and ability in managing groups, discipline, ability to set clear objectives or plans, promote products to meet standards, and aggressive marketing that can set and raise their firm performance. While community enterprises encourage the development of group members by promoting knowledge management capabilities with create, share, transfer and apply their knowledge to raise competitive advantage ) Salunke et al. 2018). Community enterprises have outstanding performance that can be mentors to raise potential capability with other community enterprises in order to transfer knowledge to professional development skills (Shiaw-Tong et al. 2016). Group leader should set policy to give opportunity for members to access more education for improve performance in the long term (Jiang et al. 2018) However, it was found that EO variables had a direct effect on the KIC. The group leader should develop EO trait of member and gives importance to develop their knowledge. Moreover, community enterprises cooperate with the educational institution to develop their knowledge from the basic to the application in order to expand knowledge as creative thinking and continue learning.

\section{Summary}

The highest of performance or opinions are CSP $(\bar{x}=3.82)$, EO ( $\bar{x}=3.81)$ and KIC ( $\bar{x}=3.74)$ respectively. The SEM was consistent with the empirical data $)^{X^{2}}=111.655, \mathrm{df}=41, \chi^{2} / \mathrm{df}=2.723, \mathrm{RMSEA}=0.067, \mathrm{SRMR}=0.01$, CFI $=$ 0.978. The results of direct and indirect influence of EO affecting the CSP of community enterprises in the three southern border provinces show that the EO has a direct influence on the KIC and has a indirectly influencing CSP by passing on the KIC (mediator) in line with the hypotheses set, while EO has not direct influence on CSP. The contributions of this research are: 1) creates the conceptual framework of CSP which received the effect from EO and indirect effect through KIC; 2) confirms the importance of EO and KIC for CSP under three southern border provinces.

\section{References}

Agricultural Offices in Yala, Pattani and Narathiwat. 2016. Population and sample size of community enterprises in three southern border provinces. Retrieved from: http://www.doae.go.th

Atalaya, M.; Anafarta, N.; \& Sarvanc, F. 2013. The relationship between innovation and firm performance: An empirical evidence from Turkish automotive supplier industry. Procedia - Social and Behavioral Sciences 75 : $226 \quad-235$. https://doi.org/10.1016/j.sbspro.2013.04.026

Awan, U.; Kraslawskib, A.; \& Huiskonenc J. 2017. Understanding the Relationship between Stakeholder Pressure and Sustainability Performance in Manufacturing Firms in Pakistan. Procedia Manufacturing 11: 768-777. http://doi.org/10.1010/j.promfg.2017.07.178

Basagliaa, S.; Caporarellob, L.; Magni, M.; \& Pennarola, F. 2010. IT knowledge integration capability and team performance: The role of team climate. International Journal of Information Management 30: 542-551. https://doi.org/10.1016/j.ijinfomgt.2010.04.003

Cantele, S.; \& Zardini, A. 2018. Is sustainability a competitive advantage for small businesses? An empirical analysis of possible mediators in the sustainability financial performance relationship. Journal of Cleaner Production 182: 166-176. https://doi.org/10.1016/i.jclepro.2018.02.016 


\section{ENTREPRENEURSHIP AND SUSTAINABILITY ISSUES}

ISSN 2345-0282 (online) http://jssidoi.org/jesi/

2020 Volume 7 Number 3 (March)

http://doi.org/10.9770/jesi.2020.7.3(2)

Covin, J.; Green, M. K.; \& Slevin, D. 2006. Strategic Process Effects on the Entrepreneurial Orientation-Sales Growth Rate Relationship. Entrepreneurship Practice and Theory Jan: 57-81. https://doi.org/10.1111/j.1540-6520.2006.00110.x

DiVito, L.; \& Bohnsack, R. 2017. Entrepreneurial orientation and its effect on sustainability decision tradeoffs: The case of sustainable fashion firms. Journal of Business Venturing 32: 569-587. https://doi.org/10.1016/j.jbusvent.2017.05.002

El Idrissi, N. E. A.; Ilham Zerrouk, I.; Naoual Zirari, N.; Salvatore Monni, S. 2020. Comparative study between two innovative clusters in Morocco and Italy. Insights into Regional Development 2(1): 400-417. http://doi.org/10.9770/IRD.2020.2.1(1)

Elkington, J. 1997. Cannibals with Forks: The Triple Bottom Line of 21st Century. Oxford: Capstone.

Fred R. D.; \& Forest R. D. 2015. Strategic Management Concepts and Cases. 15th Edition. London: Pearson Education.

Garvin, D. A. 1993. Building a learning organization. Harvard Business Review 71(4): 78-91. https://hbr.org/1993/07/building-a-learningorganization

Gold, A. H.; Malhotra, A.; \& Segars, A. H. 2001. Knowledge management: An organizational capabilities perspective. J. Management Information Systems 18(1): 185-214. https://doi.org/10.1080/07421222.2001.11045669

Grant, R. M. 1996. Toward a knowledge-based theory of the firm. Strategic Management Journal 17(S2): 109-122.

http://doi.org/10.1002/smj.4250171110

Guimarães, J., C., F.; AndreaSevero, E.; \& Vasconcelos, R., M. 2018. The influence of entrepreneurial, market, knowledge management orientations on cleaner production and the sustainable competitive advantage. Journal of Cleaner Production 174: 1653-1663. https://doi.org/10.1016/j.jclepro.2017.11.074

Hair, J. F.; Black, W.C.; Babin, B. J.; \& Anderson, R. E. 2010. Multivariate Data Analysis A Global Perspective (7 th $^{\text {th }}$ dition). New Jersey: Pearson education Inc.

Hult, G. T. M., Snow, C. C., \& Kandemir, D. (2003). The Role of Entrepreneurship in Building Cultural Competitiveness in Different Organizational Types. Journal of Management 29(3): 401-426. https://doi.org/10.1016/S0149-2063_03_00017-5

Ivanov, C-I.; \& Avasilcăi, S. 2014. Measuring the performance of innovation processes: A Balanced Scorecard perspective. Procedia Social and Behavioral Sciences 109: 1190 - 1193. https://doi.org/10.1016/j.sbspro.2013.12.610

Jiang, W.; Chai, H.; Shao, J.; \& Feng, T. 2018. Green entrepreneurial orientation for enhancing firm performance: A dynamic capability perspective. Journal of Cleaner Production 198: 1311-1323. https://doi.org/10.1016/j.jclepro.2018.07.104

Josien, L. 2012. Entrepreneurial Orientation: An Empirical study of the risk-propensity dimension of entrepreneurs. Academy of Entrepreneurship Journal 18(1): 21-34.

Kaplan, R. S.; \& Norton, D. V. 1996. Strategic learning and the balanced scorecard. Strategy and Leadership 24(5): 18-24. Retrieved from http://hbr.org

Kaplan, R.S.; \& Norton, D. P. 1997. Using the balanced scorecard as a strategic management system. Harv. Bus. Rev 74(1): 75-85. Retrieved from http://hbr.org

Kim, Y. J.; \& Sanders, G. L. 2002. Strategic actions in information technology investment based on real option theory. Decision Support System 33(1): 1-11. https://doi.org/10.1002/kpm.137

Kim, Y. J.; Song, S.; Sambamurthy, V.; \& Lee. Y.L 2012. Entrepreneurship, knowledge integration capability, and firm performance :An empirical study .Inf Syst Front 14 :1047-1060. https://doi.org/10.1007/s10796-011-9331-z

Kline, R. B. 2011. Principles and practice of structural equation modeling. ( $3^{\text {rd }}$ edition). New York: The Guilford Press.

Lesáková, L. I.; \& Dubcováb, K. I. 2016. Knowledge and Use of the Balanced Scorecard Method in the Businesses in the Slovak Republic. Procedia - Social and Behavioral Sciences 230: 39 - 48. https://doi.org/10.1016/j.sbspro.2016.09.006 


\section{ENTREPRENEURSHIP AND SUSTAINABILITY ISSUES}

ISSN 2345-0282 (online) http://jssidoi.org/jesi/

2020 Volume 7 Number 3 (March)

http://doi.org/10.9770/jesi.2020.7.3(2)

Li, Y.H.; Huang, J.W.; \& Tsai, M.T. 2009. Entrepreneurial orientation and firm performance: the role of knowledge creation process. Industrial Marketing Management 38(4): 440-449. https://doi.org/10.1016/j.indmarman.2008.02.004

Montoya, R. A. C.; Martins, I.; Velásquez, H.; \& Ceballos, H 2017. Entrepreneurial orientation, assessment and management of projects and impact in corporate entrepreneurship :intention to action .Cuadernos de Gestion 17(2): 37-61. https://doi.10.5295/cdg.140511rc

Muchiri, M. 2013. Entrepreneurial orientation and leadership: A review, model and research agenda, Proceedings of the 26th Annual Small Enterprise Association of Australia and New Zealand Conference (SEAANZ 2013), Sydney, Australia, 1-15.

Na Sakon Nakhon, T; \& Sangkharat, U. 2012. Situation and Adjustment of Retail Business in Muang District Area in Pattani, Yala, and Narathiwat Province. Prince of Songkla University. Songkla. Thailand.

National Statistical Office. 2560. Gross National Income, Gross Domestic Product and Net National Income at Current Market Prices by Economic Activities Year: 2008 - 2017. Retrieved from www.statbbi.nso.go.th

Nikolaou, I., E; \& Tsalis, T., A. 2013. Development of a sustainable balanced scorecard framework. Ecological Indicators 34: 76- 86. 10.1016/j.ecolind.2013.04.005

Norusis, M. J. (2010). SPSS 17.0 Statistical Procedures Companion. Chicago: SPSS, Inc.

Prajogo, D. I. 2007. The relationship between competitive strategies and product quality. Industrial Management \& Data Systems 107(1): 69-83. https://doi.10.1108/02635570710719061

Pratono, H. A. \& Mahmood, R. (2016). Entrepreneurial orientation and firm performance: How can small and medium-sized enterprises survive environmental turbulence?. Pacific Science Review B: Humanities and Social Sciences 1: 85-91. https://doi.10.1016/j.psrb.2016.05.003

Rovinelli, R. J.; \& Hambleton, R. K. 1977. On the use of content specialists in the assessment of criterion-referenced test item validity. Ducth Journal of Educational Research 2: 49-60.

Ryu, C.; Kim, Y. J.; Chaudhury, A.; \& Rao, H. R. 2005. Knowledge acquisition via three learning processes in enterprise information portals: Learning-by-investment, learning-by-doing, and learning from-others. MIS Quarterly 29(2): 245-278. $\underline{\text { https://doi.10.2307/25148679 }}$

Salunke, S.; Weerawardena, J.; \& McColl-Kennedy, J., R. 2018. The central role of knowledge integration capability in service innovation based competitive strategy. Industrial Marketing Management 76: 144-156. https://doi.org/10.1016/j.indmarman.2018.07.004

Salzmann, O.; Ionescu-somers, A.; \& Steger, U. 2005. The Business Case for Corporate Sustainability: Literature Review and Research Options. European Management Journal 23(1): 27-36. https://doi.org/10.1016/j.emj.2004.12.007

Sebhatu, S. P. (2008). Sustainability Performance Measurement for sustainable organizations: beyond compliance and reporting. $11^{\text {th }}$ QMOD Conference. Quality Management and Organizational Development Attaining Sustainability From Organizational Excellence to Sustainable Excellence; 20-22 August; 2008 in Helsingborg, Sweden. 75-87.

Semrau, T., Ambos, T., \& Kraus, S. 2016. Entrepreneurial orientation and SME performance across societal cultures : An international study. Journal of Business Research 69: 1928-1932. https://doi.org/10.1016/j.jbusres.2015.10.082

Shan, P., Song, M., \& Jua, Z. 2016. Entrepreneurial orientation and performance :Is innovation speed a missing link? Journal of Business Research 69: 683-690. https://doi.org/10.1016/j.jbusres.2015.08.032

Shiaw-Tong et al. )2016(. Relationship between Knowledge Management and Organizational Performance:A Test on SMEs in Malaysia. Procedia - Social and Behavioral Sciences 224: 184 - 189. https://doi.org/10.1016/j.sbspro.2016.05.438

Singh, S., H.; Bhowmick, B.; Eesley, D.; \& Sindhav, B. 2019. Grassroots innovation and entrepreneurial success: Is entrepreneurial orientation a missing link? Technological Forecasting and Social Change 119582 https://doi.org/10.1016/j.techfore.2019.02.002

Tanriverdi, H. (2005). Information technology relatedness, knowledge management capability, and performance of multibusiness firms. MIS Quarterly 29(2): 311-334. 


\section{ENTREPRENEURSHIP AND SUSTAINABILITY ISSUES}

ISSN 2345-0282 (online) http://jssidoi.org/jesi/

2020 Volume 7 Number 3 (March)

http://doi.org/10.9770/jesi.2020.7.3(2)

Tuğçe K. Z.; \& Vayvaya, O. 2016. The Fifth Pillar of the Balanced Scorecard: Sustainability. Procedia - Social and Behavioral Sciences 235: 76-83. https://doi.org/10.1016/j.sbspro.2016.11.027

Wiersma, W.; \& Jur, S. G. 2009. Research Methods in Education an Introduction. (9th ed.). Boston, MA: Pearson Education Inc.

Zehir, C., Can, E., \& Karaboga, T. 2015. Linking entrepreneurial orientation to firm performance :the role of differentiation strategy and innovation performance. Procedia -Social and Behavioral Sciences 210: 358 -367. http://doi.org/10.1016/j.sbspro.2015.11.381

Zhang, W.; Padmanabhan, P.; \& Huang, C. 2018. Firm level offshoring activities, pollution regulation, triple bottom line, and market structure: What do they have in common? Journal of Cleaner Production 195: 618-624. https://doi.org/10.1016/j.jclepro.2018.05.232

\section{Acknowledgement}

Thanks to the Office of the Higher Education Commission for allocating a national PhD scholarship in the project to develop teachers and personnel for higher education institutions in the development zone of the southern border provinces for the year 2018. Data was collected from the research samples that have passed the approval of the Human Research Program in Humanities and Social Sciences, Suranaree University of Technology, Thailand Project Code EC-62-0031. 


\section{ENTREPRENEURSHIP AND SUSTAINABILITY ISSUES}

ISSN 2345-0282 (online) http://jssidoi.org/jesi/

2020 Volume 7 Number 3 (March)

http://doi.org/10.9770/jesi.2020.7.3(2)

Dussadee NAKRUANG is an Assistant Professor at Faculty of Management Sciences, Yala Rajabhat University. She is currently a Ph.D. Candidate in Management at Suranaree University of Technology, Thailand. Her thesis is focused on corporate sustainability performance, entrepreneurship and knowledge management.

ORCID ID: orcid.org/0000-0002-1812-6299

Kwunkamol DONKWA is an Associate Professor at the School of Management Technology, Institute of Social Technology, Suranaree University of Technology. She holds the Ph.d. (Agricultural Economics) degree from Kasetsart University, Thailand. Her current research interests include economics, community's economy and entrepreneurship.

ORCID ID: orcid.org/0000-0003-3429-3924

Adisak SUVITTAWAT is an Assistant Professor at the School of Management Technology, Institute of Social Technology, Suranaree University of Technology. He holds the DBA degree from Asian Institute of Technology, Thailand. His current research interests include supply chain management, service quality, logistics and entrepreneurship.

ORCID ID: orcid.org/0000-0001-5225-5804

Register for an ORCID ID:

https://orcid.org/register

Copyright (C) 2020 by author(s) and VsI Entrepreneurship and Sustainability Center

This work is licensed under the Creative Commons Attribution International License (CC BY).

http://creativecommons.org/licenses/by/4.0/

(c) † Open Access 